J. Clin. Chem. Clin. Biochem.

Vol. 27, 1989, pp. $141-149$

(C) 1989 Walter de Gruyter \& Co.

Berlin - New York

\title{
Comparison of Sulphated Glycosaminoglycan and Hyaluronate Synthesis and Secretion in Cultured Hepatocytes, Fat Storing Cells, and Kupffer Cells
}

\author{
By A. M. Gressner and S. Schäfer \\ Abteilung für Klinische Chemie und Zentrallaboratorium, Philipps-Universität, Marburg, FRG
}

(Received August 30/November 22, 1988)

Summary: The extracellular matrix of normal liver contains several types of proteoglycans including heparan sulphate, chondroitin sulphate isomers, dermatan sulphate, and the glycosaminoglycan, hyaluronic acid. In the present study both the synthesis and secretion as well as the pattern of radioactively labeled proteoglycans and hyaluronic acid of hepatocytes, fat-storing cells (Ito cells), and Kupffer cells maintained in monolayer cultures under mostly identical conditions were compared to assess their relative contribution to hepatic proteoglycan synthesis. Fat-storing cells were identified as the main type of cell producing and secreting proteoglycan and hyaluronic acid. More than $70 \%$ of labeled proteoglycan and hyaluronic acid were secreted into the medium. Heparan sulphate is the main type of proteoglycan in hepatocytes, whereas in the medium of fat-storing cells, chondroitin sulphate and dermatan sulphate comprise the major fractions. Hyaluronic acid was not detectable in hepatocyte cultures and found only in low amounts in the medium of Kupffer cells. The results point to a stringent quantitative and qualitative cellular compartmentation of proteoglycan synthesis in liver with fat-storing cells as the most important cell type for matrix proteoglycan and hyaluronic acid production.

\section{Introduction}

The main components of the extracellular matrix of human and animal liver are several types of collagens (I, III, IV, V, VI), some structural glycoproteins (fibronectin, laminin), a group of proteoglycans (proteoheparan sulphate, proteochondroitin sulphate, proteodermatan sulphate), and hyaluronic acid $(1-4)$. The cellular sources of the matrix molecules have been identified only partially. Whereas the formation of specific types of collagens $(5-18)$, fibronectin $(19-21)$, and of the basement membrane glycoprotein laminin (22) has been demonstrated by immunocytochemical and cell culture techniques in parenchymal (5-14) and non-parenchymal (15-22) cells, muich less is known about the cell-type-specific formation of proteoglycans and hyaluronate. Recently, we demonstrated the ability of cultured fat storing cells to'produce sulphated proteoglycans (23) and hyaluronate (24). Neither glycosaminoglycan syn- thesis nor secretion in cultures of parenchymal and other non-parenchymal cells were evaluated under comparable conditions. Information on the relative contribution of the various cell types to hepatic proteoglycan and hyaluronate synthesis will be important since under pathological conditions like liver fibrosis $(25-28)$ and hepatocellular carcinoma $(29,30)$, both the total glycosaminoglycan content and the pattern of sulphated and non-sulphated glycosaminoglycans change greatly. In the present study we attempted to compare the synthesis, secretion, and molecular profile of glycosaminoglycans of hepatocytes, fat-storing cells; and Kupffer cells kept in culture under largely identical conditions. The results indicate that the fat storing cell, a sinusoidal type of non-parenchymal liver cell engaged primarily in the storage and metabolism of retinoids $(31,32)$, is the most important cell type in hepatic proteoglycan and hyaluronate synthesis. 


\section{Materials and Methods}

Isolation and culture of hepatocytes, fat-storing cells, and Kupffer cells

All cells were prepared from male Sprague Dawley rats (Lippische Versuchstierzucht, Extertal, FRG) receiving a standard lab chow diet (type Han MR5 containing $15 \mathrm{kU}$ vitamin A per $\mathrm{kg}$ ) and water ad libitum.

Hepatocytes were isolated from rats $(250-320 \mathrm{~g}$ body weight, fasted overnight) by the method of Seglen (33) incorporating slight modifications (34). The rats were anaesthetized with an intraperitoneal injection of phenobarbital $\left(\mathrm{Nembutal}^{\circledR}, 54 \mathrm{mg} /\right.$ $\mathrm{kg}$ body weight) and the liver was preperfused in situ via the portal vein in a non-circulating way for $10 \mathrm{~min}$ with $\mathrm{Ca}^{2+}$-free Hank's balanced salt solution, $\mathrm{pH} 7.4$ at $37^{\circ} \mathrm{C}$, at a flow rate of $0.03 \mathrm{l} / \mathrm{min}$, followed by recirculating perfusion ex situ for a further $15 \mathrm{~min}$ with $\mathrm{Ca}^{2+}(5 \mathrm{mmol} / \mathrm{l})$, collagenase $(0.5 \mathrm{~g} / \mathrm{l}$, Clostridium histolyticum, type I, Sigma Chem. Co., Munich, FRG) and deoxyribonuclease $(0.05 \mathrm{~g} / \mathrm{l}$, bovine pancreas, type I, Boehringer GmbH, Mannheim, FRG) containing oxygenated Hank's balanced salt soltuion, $\mathrm{pH} 7.4$ at $37^{\circ} \mathrm{C}$, at a flow rate of 0.05 $1 / \mathrm{min}$. Thereafter, the liver capsule was gently removed, the tissue was dissected and incubated in $100 \mathrm{ml}$ collagenase-containing oxygenated Hank's buffer for $10 \mathrm{~min}$ at $37^{\circ} \mathrm{C}$ under constant swirling, after which the material was filtered through double layer of sterile gauze. The initial cell suspension obtained in the filtrate was purified by differential centrifugation, first for $2 \mathrm{~min}$ at $36 \mathrm{~g}$, then twice for $2 \mathrm{~min}$ at $17 \mathrm{~g}$, all at $4^{\circ} \mathrm{C}$. The viability of the final parenchymal cell suspension, checked by trypan blue exclusion $(2.5 \mathrm{~g} / \mathrm{l})$, was between 80 and $90 \%$, the cell recovery was between $2 \cdot 10^{8}$ and $5 \cdot 10^{8}$ cells/liver, and the contamination with non-parenchymal cells was less than $1 \%$. Cells were seeded at a density of $0.12 \cdot 10^{6} \mathrm{cells} / \mathrm{cm}^{2}$ in 6-well plates (diameter $35 \mathrm{~mm}$, Greiner $\mathrm{GmbH}$, Nürtingen, FRG) and cultured in $5 \mathrm{ml}$ Ham's F12 medium (Boehringer GmbH, Mannheim, FRG) supplemented with $4 \mathrm{mmol} / \mathrm{l} \mathrm{L}$-glutamine, fetal calf serum, volume fraction 0.1 (Boehringer $\mathrm{GmbH}$ ), penicillin $(100 \mathrm{kU} / \mathrm{l})$, streptomycin $(100 \mathrm{mg} / \mathrm{l})$, and $20 \mathrm{U} / \mathrm{l}$ insulin (bovine pancreas, Sigma Chem. Co., FRG). The first change of medium was $3 \mathrm{~h}$ after plating, during which non-adherent and dead cells were removed. Thereafter, the medium was changed daily. Cells were kept at $37^{\circ} \mathrm{C}$ in a humidified atmosphere of $0.05 \mathrm{CO}_{2}$ and 0.95 air.

Fat-storing cells (perisinusoidal lipocytes) were prepared from 1 year old rats (body weight $500-700 \mathrm{~g}$ ). Nonparenchymal liver cells were isolated by the pronase-collagenase method of de Leeuw et al. (35) in a sequence of non- and recirculating perfusions incorporating some minor modifications described in detail elsewhere (23). Fat-storing cells were purified from the non-parenchymal liver cell suspension by single-step density gradient centrifugation with Nycodenz $z^{\text {(w) }}$ (analytical grade, Nyegaard and Co. AS, Oslo, Norway), exactly as described previously (23). The purity of freshly isolated cells used in this study was at least $90 \%$, cell viability checked by trypan blue exclusion was more than $80 \%$, and the yield ranges from $5 \cdot 10^{6}$ to $60 \cdot 10^{6}$ cells per liver. After the first change of medium most of the contaminating cells were removed, and the monolayers were essentially free of impurities. Fat-storing cells were identified by their typical light microscopic appearance, transmission electron microscopy (23), positive immunofluorescence staining for desmin (36), and vitamin A-specific autofluorescence at an excitation wavelength of $328 \mathrm{~nm}$ (23). The cells were seeded at an initial density between 0.25 and $0.40 \cdot 16^{6} / 2 \mathrm{~cm}^{2}$ and maintained as monolayers in 24-well culture plates (Falcon ${ }^{\oplus}$, Becton \& Dickinson, Oxnard, USA) in $1 \mathrm{ml} / 2 \mathrm{~cm}^{2}$ well of Dulbecco's modification of Eagles medium (Flow Laboratories GmbH, Bonn, FRG) containing $4 \mathrm{mmol} / \mathrm{l} \mathrm{L}$-glutamine, penicillin (100 $\mathrm{kU} / \mathrm{l})$, streptomycin $(100 \mathrm{mg} / \mathrm{l})$ and fetal calf serum, volume fraction 0.1 (Boehringer $\mathrm{GmbH}$ ) in a humidified atmosphere of $0.05 \mathrm{CO}_{2}$ and 0.95 air. The first change of medium was made about $20 \mathrm{~h}$ after seeding, the subsequent changes were made daily.
Kupffer cells were isolated either simultaneously with or (more frequently) separately from fat-storing cells. The sinusoidal cell suspension was prepared and purified with a single-step $\mathrm{Ny}$ codenz $z^{\natural}$ gradient as described above. The cell sedimenit obtained after Nycoden $z^{(1)}$ gradient centrifugation was resuspended in Gey's balanced salt solution and washed by centrifugation $\left(450 \mathrm{~g}, 7 \mathrm{~min}, 4^{\circ} \mathrm{C}\right)$. The sediment was gently suspended in Gey's solution supplemented with $3 \mathrm{~g} / \mathrm{l}$ bovine serum albumin and subjected to centrifugal elutriation at $4{ }^{\circ} \mathrm{C}$ for purification of Kupffer cells in a JE-,6B type rotor equipped with a standard separation chamber, using a Beckman model J-6B centrifuge. Details of the procedure have been described previously (37). Kupffer cells recovered from elutriation were collected by centrifugation for $7 \mathrm{~min}$ at $450 \mathrm{~g}$ and $4^{\circ} \mathrm{C}$ and resuspended in the same culture medium described above for fat-storing cells. The cells were seeded at a density between 0.25 and $0.40 \cdot 10^{6}$ cells $/ 2 \mathrm{~cm}^{2}$ in 24-well plates and incubated in $1 \mathrm{ml}$ of Dulbecco-medium (described above). The viability as checked by trypan blue exclusion was greater than $90 \%$. Ideritification and assessment of the purity of the Kupffer cells were performed by light- and electron microscopy (38), peroxidase staining, by phagocytosis of latex beads (LB 11 polystyrene beads, mean diameter $1.1 \mu \mathrm{m}$; Sigma Chem. Co., St. Louis, USA) for 60 min at $37^{\circ} \mathrm{C}(23)$, and by demonstration of positive immunofluorescence staining for vimentin and negative staining for desmin (39). According to these criteria the purity of seeded Kupffer cells was greater than $95 \%$. The first medium change was made $12 \mathrm{~h}$ after seeding, the subsequent changes were performed every $24 \mathrm{~h}$.

Determination of the synthesis of total and specific types of glycosaminoglycans

The synthesis of sulphated glycosaminoglycans was determined by the incorporation of either $\left[{ }^{35}\right.$ S] sulphate $(18.5-22.2 \mathrm{GBq} /$ mmol; $740 \mathrm{MBq} / 1$ medium; New England Nuclear Corp., Böton, USA) or $D-\left[6-{ }^{3} \mathrm{H}\right]$ glucosamine hydrochloride $(1.48 \mathrm{TBq} /$ mmol; $740 \mathrm{MBq} / \mathrm{l}$ medium, Amersham Buchler GmbH, Braunschweig, FRG) during a labeling period of $24 \mathrm{~h}$. The addition of isotopes (usually on the 3rd day of primary culture) was preceded by a change of medium. In hepatocyte cultures, Ham's F12 medium was replaced by supplemented Dulbecco's modification of Eagles medium without insulin; the hepatocyte medium during labelling was therefore identical to that of the fatstoring cells and Kupffer cells. Labeled glycosaminoglycans were measured separately in the medium and cell-layer of the cultures. After taking off the medium the cell layer was rinsed three times with phosphate-buffered saline. The cells were detached from the well by three cycles of freezing (with liquid nitrogen) and thawing and rinsed out with water. Alternatively, cells were detached by trypsinization $\left(5 \mathrm{~min}\right.$ at $\left.37^{\circ} \mathrm{C}\right)$ with trypsin $(2.5 \mathrm{~g} / \mathrm{l})$ and EDTA $(1 \mathrm{~g} / \mathrm{l})$ in phosphate-buffered saline, pH 7.4. Less than $1 \%$ of total glycosaminoglycan radioactivity remained in the well. Glycosaminoglycans were isolated from the cell-free medium (after centrifugation for $6 \mathrm{~min}, 1000 \mathrm{~g}$, $4^{\circ} \mathrm{C}$ ) and from the cells by exhaustive proteolysis in $0.1 \mathrm{~mol} / \mathrm{l}$ sodium acetate, $\mathrm{pH}$ 6.1, with papain (EC 3.4.22.2, Boehringer $\mathrm{GmbH}$, Mannheim, FRG) for $48 \mathrm{~h}$ at $60^{\circ} \mathrm{C}(23,34)$, followed by batchwise $(0.3$ to $2.2 \mathrm{~mol} / \mathrm{l} \mathrm{NaCl})$ chromatography on DEAE-Sephacel as described (24). The efficiency of proteolytic glycosaminoglycan extraction from cells and medium was more than $90 \%$. The radioactivity of an aliquot of total labeled glycosaminoglycans was determined, and radioactivity was then expressed on the basis of the cell number, DNA content, and protein content of the cultures, respectively.

For analysis of specific types of glycosaminoglycan, total glycosaminoglycans were subjected to consecutive degradations with nitrous acid to obtain the incorporation of label into heparan sulphate, and to enzymatic digestion with chondroitin AC-(EC 4.2.2.5) and -ABC-lyases (EC 4.2.2.4) (Seikagaku Fine Chemicals, Tokyo, Japan) to obtain the fractions of chondroitin 4,6-sulphate and dermatan sulphate, respectively. Analytical 
details of the procedure are reported elsewhere $(23,29,34,40)$. Total degradation efficiency was determined by the degradation of biosynthetically labeled rat liver heparan sulphate and of in vitro $\mathrm{N}-\left[{ }^{3} \mathrm{H}\right]$ acetyl-labeled chondroitin sulphate and dermatan sulphate (Sigma Chemical Company); the efficiency of degradation was found to be between 85 and $96 \%$ (23).

Determination of radioactively labeled hyaluronic acid

Total $\left[{ }^{3} \mathrm{H}\right.$ ]glucosamine-labeled glycosaminoglycans were isolated by batchwise DEAE-sephacel chromatography as described above but the resin was initially equilibrated with 0.1 $\mathrm{mol} / \mathrm{l}$ sodium acetate, $\mathrm{pH} 6.2$ before the absorbed material was eluted with $2.2 \mathrm{~mol} / 1 \mathrm{NaCl}$. The glycosaminoglycans in the eluate were precipitated with $4 \mathrm{ml}$ absolute ethanol for $12 \mathrm{~h}$ at room temperature, then washed with absolute ethanol to remove $\mathrm{NaCl}$ and subjected to enzymatic digestion with hyaluronate lyase (EC 4.2.2.1, from Streptomyes hyalurolyticus, Seikagaku Co., Tokyo, Japan). Portions of $200 \mu \mathrm{l}$ were incubated for $3 \mathrm{~h}$ at $60{ }^{\circ} \mathrm{C}$ in $0.033 \mathrm{~mol} / \mathrm{l}$ sodium acetate, $\mathrm{pH} 5.0$ with 5 TRU hyaluronate lyase in a total reaction volume of $1 \mathrm{ml}$. Control incubations were performed with a similar volume of $0.1 \mathrm{~mol} / 1 \mathrm{NaCl}$ instead of enzyme. After termination of the reaction by cooling in ice those glycosaminoglycans not degraded by hyaluronate lyase were precipitated for $16 \mathrm{~h}$ at room temperature with 4 volumes of ethanol saturated with sodium acetate, and centrifuged $(4500 \mathrm{~g}, 10 \mathrm{~min})$. The sediment was dried, dissolved in water and counted for radioactivity. The amount of labeled hyaluronic acid was calculated from the difference between the control and enzyme incubations. The analytical criteria of this method have been reported (37).

Determination of hyaluronic acid concentration in the medium

Hyaluronate was measured with a radiometric assay (Pharmacia Diagnostics AB, Uppsala, Sweden) based on principles described in detail elsewhere (41). Briefly, a ${ }^{125}$ I-labeled cartilage protein with specific affinity for hyaluronate binds to hyaluronic acid in the medium. The unbound fraction of the hyaluronate binding protein is then quantitated by binding to hyaluronate covalently coupled to sepharose. Thus, the radioactivity bound to the particles is inversely proportional to the concentration of hyaluronate in the medium. It was ascertained that the test was specific for hyaluronic acid by showing that no hyaluronate could be measured after digestion of the sample with hyaluronate lyase as described above. In each case the hyaluronic acid concentration of the complete culture medium before contact with fat-storing cells was determined (between 86.6 and $94.3 \mu \mathrm{g} / \mathrm{l}$ ) and subtracted from the concentration measured after incubation with the cells.

\section{General techniques}

Cells were quantitated either by counting in a haemocytometer or by fluorometric determination of DNA (42) using calf thymus DNA (type I, Sigma Chem. Co., Munich, FRG) as a standard. Protein was determined by the method of Lou'ry et al. (43) using bovine serum albumin as a calibrator. Cell viability was determined with the trypan blue exclusion test.

\section{Results}

\section{General characterization of cultured cells}

The cells were cultured for up to 4 days as monolayers, during which time they expressed a typical morphology (fig. 1). Hepatocytes formed trabeculae-like structures, and some cells contained more than one nu-
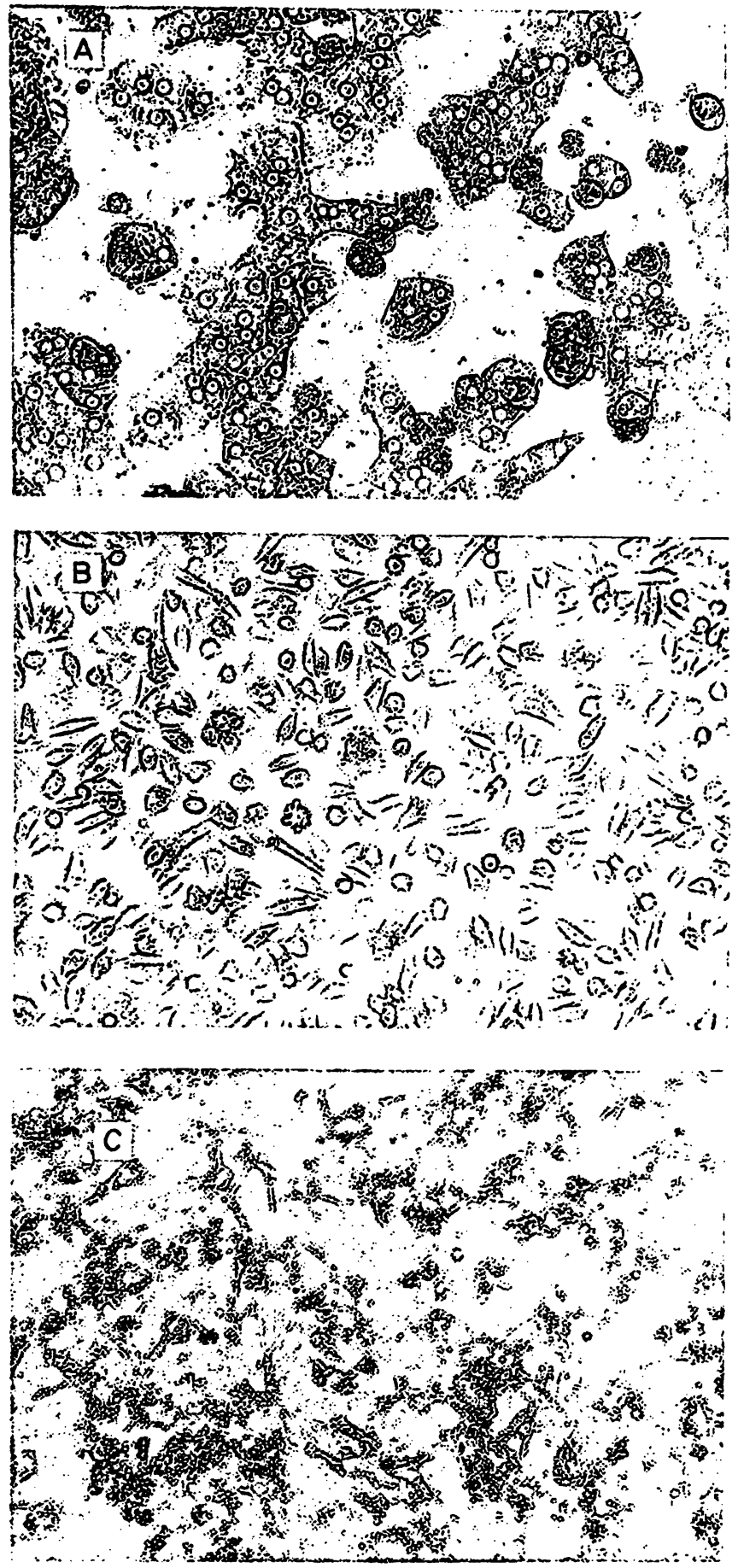

Fig. 1. Light microscopic appearance of hepatocytes (A), Kupffer cells (B), and fat-storing cells (C) all on the 3rd day of primary monolayer culture. Hepatocytes form trabeculae-like structures and often contain more than one nucleus. Kupffer cells are spindle-shaped; fat-storing cells are easily identified by numerous cytoplasmic fat droplets and long cellular extensions, which form a network. Magnification 160x.

cleus. The mean viability of the cells on the 3 rd day of culture was $85 \%$, and contaminating non-parenchymal cells were absent, as determined by the methods described above. Fat-storing cells were characterized by abundant fat droplets (fig. 2) showing intense (vitamin A) fluorescence upon irradiation at $328 \mathrm{~nm}$. 


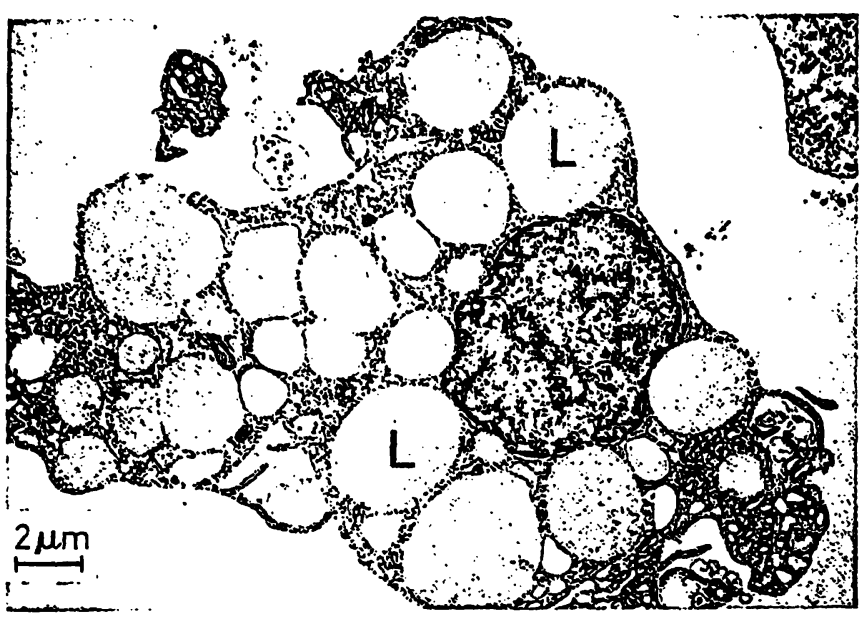

Fig. 2. Electron micrograph of a fat-storing cell isolated from rat liver. Multiple lipid (vitamin A-containing) droplets (L). Bar $=2 \mu \mathrm{m}$.

On the 3rd culture day they showed long cellular extensions and a typical stellate shape. The cultures were free of hepatocytes, and phagocytosing and peroxidase-positive cell contaminations were estimated to be less than $5 \%$. More than $85 \%$ of fat-storing cells on the 3rd culture day excluded trypan blue. Kupffer cells had a spindle-shaped cell body with several protrusions; they all rapidly phagocytosed latex beads, and their viability was about $90 \%$. Hepatocytes were absent from these cultures, whereas traces (about $2 \%$ ) of contaminating fat-storing cells could not be avoided in a great number of cell isolations. It was established that protein synthesis measured by incorporation of $\left[{ }^{3} \mathrm{H}\right]$ valine into total cellular protein in cultures of all cell types preceded linearly for at least $24 \mathrm{~h}$ (data not shown). Hepatocytes and non-parenchymal cells showed different DNA- and protein-contents and different protein/DNA ratios, all parameters being higher in hepatocytes. In fatstoring cells and Kupffer cells these parameters were in the same order of magnitude (tab. 1).

Tab. 1. Protein and DNA contents of freshly isolated fat-storing cells, hepatocytes, and Kupffer cells. Cells were counted in a haemocytometer; DNA and protein were determined in cell lysates prepared by sonification. Mean values $\pm S$. D. of 3 independent cell isolations are shown.

\begin{tabular}{lrrl}
\hline Cell type & $\begin{array}{l}\text { DNA } \\
\left(\mu \mathrm{g} / 10^{6} \text { cells }\right)\end{array}$ & $\begin{array}{l}\text { Protein } \\
\left(\mu \mathrm{g} / 10^{6} \text { cells }\right)\end{array}$ & $\begin{array}{l}\text { Ratio } \\
\text { protein/ } \\
\text { DNA }\end{array}$ \\
\hline Fat-storing cells & $10.5 \pm 3.1$ & $165 \pm 13$ & 16 \\
Hepatocytes & $25.9 \pm 1.6$ & $1220 \pm 74$ & 47 \\
Kupffer cells & $6.8 \pm 1.8$ & $132 \pm 22$ & 19 \\
\hline
\end{tabular}

Comparison of total sulphated glycosaminoglycan synthesis and secretion in hepatocytes and non-parenchymal cells

On the 3rd day of culture, each cell type was exposed for $24 \mathrm{~h}$ under identical conditions to $\left[{ }^{35} \mathrm{~S}\right]$ sulphate and $\left[{ }^{3} \mathrm{H}\right]$ glucosamine, to determine the incorporation of these precursors into the total glycosaminoglycans of cells and medium. Fat-storing cells showed the highest rate of $\left.{ }^{35} \mathrm{~S}\right]$ sulphate-labeled glycosaminoglycan synthesis. When related to cell number, the amount of labeled polysaccharide in hepatocytes was about one third of that measured in fat-storing cells. When related to the DNA- or to the protein-content, the rate of incorporation of $\left[{ }^{35} \mathrm{~S}\right]$ sulphate into glycosaminoglycans in hepatócytes was only $12 \%$ or $4 \%$, respectively, of that in fat-storing cells (fig. 3). Kupffer cells contained only 4 to $8 \%$ of sulphated glycosaminoglycans when compared with fat-storing cells.
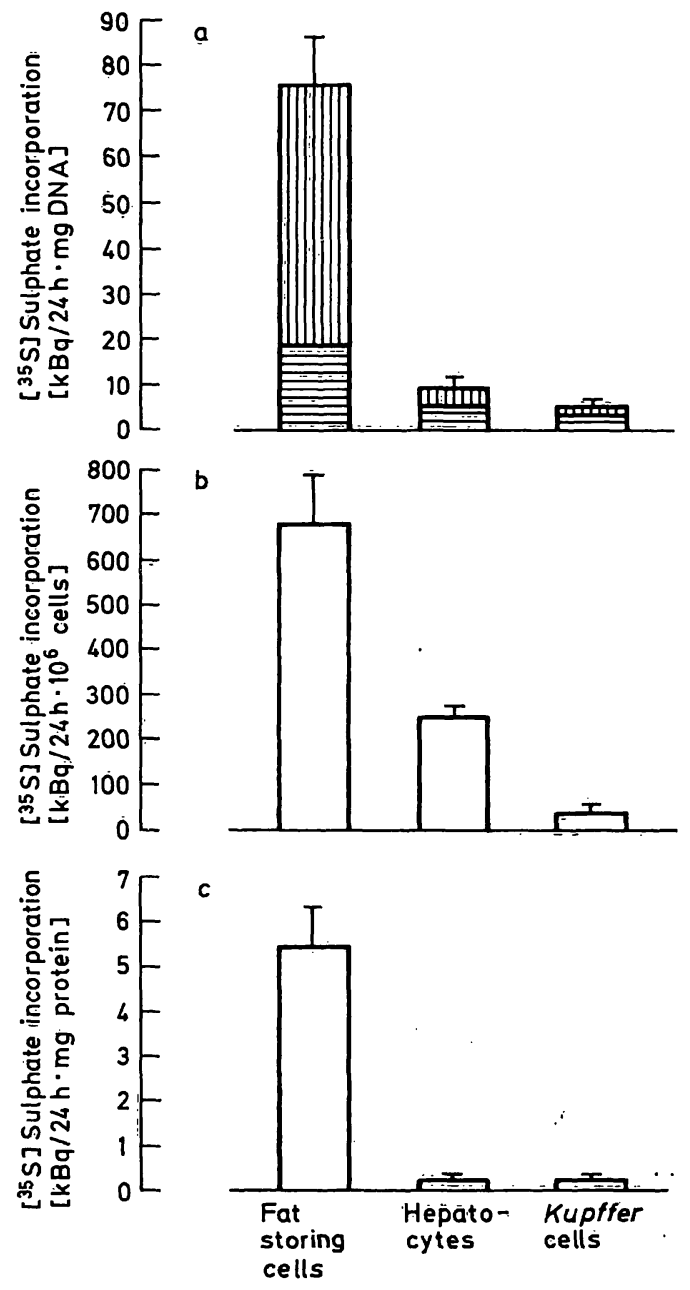

Fig. 3. Incorporation of $\left[{ }^{35}\right.$ S $]$ sulphate into total glycosaminoglycans of a) fat-storing cells, b) hepatocytes, and c) Kupffer cells on the 3 rd day of primary culture. After labeling for $24 \mathrm{~h}$ with $0.37 \mathrm{MBq}\left[{ }^{35}\right.$ S] sulphate per $5 \mathrm{ml}$ medium, glycosaminoglycans of cells (哯) and medium (四) were analysed separately. Rates of incorporation are referred to cellular DNA, protein, and cell numbèr, respectively. Mean values \pm S. D. of 4 independent ex„periments are shown. 
Thus, the proportional rates of sulphate incorporation in fat-storing cells, hepatocytes, and Kupffer cells were 4:0.5: 0.2 (referred to DNA content). Somewhat different proportions were obtained when $\left[{ }^{3} \mathrm{H}\right]$ glucosamine was used as an isotopic precursor (tab. 2), but these data also demonstrate that fatstoring cells are most active in the synthesis of labeled glycosaminoglycans.

Tab. 2. Incorporation of $\left[{ }^{3} \mathrm{H}\right]$ glucosamine into total glycosaminoglycans of fat-storing cells, hepatocytes, and Kupffer cells. The cells were incubated on the 3rd day of primary culture with $0.37 \mathrm{MBq}$ of $\left[{ }^{3} \mathrm{H}\right]$ glucosamine per $5 \mathrm{ml}$ medium. Glycosaminoglycans of cells and medium were analysed separately. Rates of incorporation are related to cellular DNA and protein, respectively. Mean values $\pm S$. D. of 4 experiments are listed.

\begin{tabular}{lrrr}
\hline Cell type & \multicolumn{3}{l}{$\begin{array}{l}\left.{ }^{3} \mathrm{H}\right] \text { glucosamine incorporation } \\
(\mathrm{kBq} / \mathrm{mg} \mathrm{DNA} \cdot 24 \mathrm{~h})\end{array}$} \\
\cline { 2 - 4 } & \multicolumn{1}{l}{ total } & \multicolumn{1}{c}{ cells } & medium \\
\hline Fat-storing cells & $47.5 \pm 2.0$ & $10.0 \pm 0.5$ & $37.5 \pm 1.6$ \\
Hepatocytes & $27.0 \pm 2.0$ & $18.3 \pm 2.3$ & $8.7 \pm 0.2$ \\
Kupffer cells & $3.8 \pm 0.3$ & $1.8 \pm 0.2$ & $2.0 \pm 0.3$ \\
\hline & \multicolumn{4}{l}{ (kBq/mg protein $\cdot 24 \mathrm{~h})$} \\
\cline { 2 - 4 } & total & cells & medium \\
\hline Fat-storing cells & $3.4 \pm 0.22$ & $0.7 \pm 0.07$ & $2.7 \pm 0.22$ \\
Hepatocytes & $0.6 \pm 0.04$ & $0.4 \pm 0.05$ & $0.2 \pm 0.04$ \\
Kupffer cells & $0.2 \pm 0.03$ & $0.1 \pm 0.01$ & $0.1 \pm 0.02$ \\
\hline
\end{tabular}

The secretion rates of labeled glycosaminoglycans into the medium were found to be strikingly different between the various cell types (fig. 3, tab. 2). Most of newly formed $\left[{ }^{35} \mathrm{~S}\right]$ sulphate- or $\left[{ }^{3} \mathrm{H}\right]$ glucosamine-labeled polysaccharides in fat-storing cells were secreted (fractions of 0.7 to 0.8 ) but in hepatocytes glycosaminoglycans remained predominantly cell-associated (about 0.7 ). Nearly 0.8 of Kupffer cell-derived glycosaminoglycans were found in the cell layer.

Comparison of type-specific glycosaminoglycan synthesis and secretion in hepatocytes and non-parenchymal cells

The profile of $\left[{ }^{35} S\right]$ sulphate-labeled glycosaminoglycans in fat-storing cells and Kupffer cells was significantly different from that of hepatocytes (fig. 4). In parenchymal liver cells heparan sulphațe contributed about $90 \%$, while chondroitin sulphate and dermatan sulphate comprised less than $10 \%$ of total labeled glycosaminoglycans. In the medium of hepatocyte cultures, about $50 \%$ of nitrous acid labile material (heparan sulphate) and about $35 \%$ chondroitin sulphate were found. In the medium of fat-storing cell cultures, dermatan sulphate (DS) and chondroitin sulphate (CS) were found to be the major fractions, whereas heparan sulphate (HS) was the predominant type in the cell layer (fig. 4). The pattern of sulphated glycosaminoglycans in fat-storing cells (CS : DS : HS $=1: 0.6: 1.7)$ resembled closely that of Kupffer cells (CS:DS:HS $=1: 0.7: 1.4$ ). In the medium of the latter cell type the individual glycosaminoglycans were present in nearly equal portions (fig. 4). A comparison of incorporation rates of $\left[{ }^{35} \mathrm{~S}\right]$ sulphate into specific types of glycosaminoglycans of hepatocytes and fatstoring cells showed that fat-storing cells secreted nearly 11 times more labeled chondroitin sulphate and even 900 times more dermatan sulphate into the medium than the corresponding hepatocytes (tab. 3). Fat-storing cells secreted a fraction of almost 0.8 of labeled glycosaminoglycans into the medium, and hepatocytes secreted 0.37 of newly formed polysaccharides. In fat-storing cells, the fractional secretion rates of chondroitin sulphate and dermatan sulphate amounted 0.76 , and that of heparan sulphate was 0.32 .

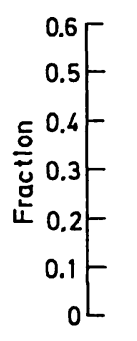
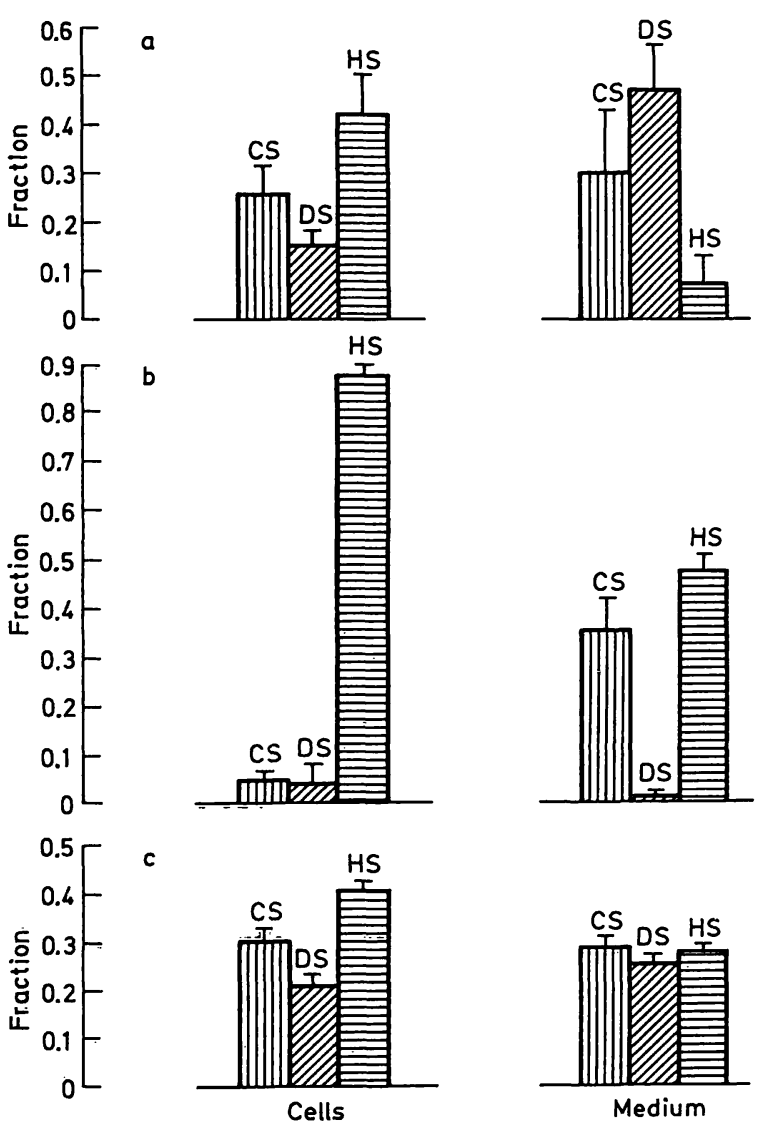

Fig. 4. Pattern of specific types of sulphated glycosaminoglycans in cells (left) and medium (right) determined by the fractional rates of incorporation of $\left[{ }^{35}\right.$ S]sulphate into individual glycosaminoglycans of a) fat-storing cells, b) hepatocytes, and c) Kupffer cells, respectively. Cells were incubated with $\left[{ }^{35}\right.$ S]sulphate for $24 \mathrm{~h}$ as described in figure 2. Glycosaminoglycans of cells and medium were isolated and specified by enzymatic and chemical degradation. The amount of a specific type is expressed relative to that of total labeled glycosaminoglycans. Mean values \pm S. D. of 3 experiments are shown. 四 $=$ chondroitin sulphate; $=$ dermatan sulphate; 目 $=$ heparan sulphate. 
Tab. 3. Incorporation of ${ }^{35}$ S $]$ sulphate into specific types of glycosaminoglycans of fat-storing cells and hepatocytes on the 3rd day of culture. Cells were exposed for $24 \mathrm{~h}$ to $0.74 \mathrm{MBq}\left[{ }^{35}\right.$ S]sulphate per $5 \mathrm{ml}$ medium. Cells and medium were analysed separately for individual types of labeled glycosaminoglycans. Mean values \pm S. D. of 4 experiments are listed.

\begin{tabular}{|c|c|c|c|c|c|}
\hline \multirow{3}{*}{$\begin{array}{l}\text { Cell type } \\
\text { Fat-storing cells }\end{array}$} & \multirow{3}{*}{$\begin{array}{l}\text { Glycosaminoglycan } \\
\begin{array}{l}\text { Chondroitin sulphate } \\
\text { Dermatan sulphate } \\
\text { Heparan sulphate }\end{array}\end{array}$} & \multicolumn{3}{|c|}{$\begin{array}{l}{\left[{ }^{35} \mathrm{~S}\right] \text { sulphate incorporation }} \\
(\mathrm{kBq} / \mathrm{mg} \text { DNA } \cdot 24 \mathrm{~h})\end{array}$} & \multirow{3}{*}{$\begin{array}{l}\text { Ratio } \\
\text { medium/cells } \\
3.5 \\
9.2 \\
0.5\end{array}$} \\
\hline & & cells & medium & total & \\
\hline & & $\begin{array}{l}4.9 \pm 0.7 \\
2.9 \pm 0.4 \\
8.1 \pm 1.2\end{array}$ & $\begin{array}{r}17.3 \pm 4.0 \\
26.0 \pm 6.2 \\
4.4 \pm 1.0\end{array}$ & $\begin{array}{l}22.2 \pm 3.4 \\
29.8 \pm 5.2 \\
12.5 \pm 0.9\end{array}$ & \\
\hline Hepatocytes & $\begin{array}{l}\text { Chondroitin sulphate } \\
\text { Dermatan sulphate } \\
\text { Heparan sulphate }\end{array}$ & $\begin{array}{l}0.3 \pm 0.01 \\
0.2 \pm 0.01 \\
4.8 \pm 0.26\end{array}$ & $\begin{array}{l}1.5 \pm 0.07 \\
0.03 \pm 0.00 \\
2.05 \pm 0.10\end{array}$ & $\begin{array}{l}1.8 \pm 0.08 \\
0.3 \pm 0.01 \\
6.9 \pm 0.53\end{array}$ & $\begin{array}{l}6.2 \\
0.1 \\
0.4\end{array}$ \\
\hline Kupffer cells & $\begin{array}{l}\text { Chondroitin sulphate } \\
\text { Dermatan sulphate } \\
\text { Heparan sulphate }\end{array}$ & $\begin{array}{l}1.20 \pm 0.15 \\
0.83 \pm 0.10 \\
1.62 \pm 0.20\end{array}$ & $\begin{array}{l}0.29 \pm 0.05 \\
0.25 \pm 0.04 \\
0.28 \pm 0.05\end{array}$ & $\begin{array}{l}1.55 \pm 0.25 \\
1.13 \pm 0.16 \\
1.96 \pm 0.29\end{array}$ & $\begin{array}{r}0.2 \\
\cdot 0.3 \\
0.2\end{array}$ \\
\hline
\end{tabular}

Comparison of hyaluronic acid synthesis and secretion in hepatocytes and non-parenchymal cells

The synthesis rate of $\left[{ }^{3} \mathrm{H}\right]$ glucosamine-labeled glycosaminoglycans in the medium of fat-storing cells increased with advancing culture time (fig. 5). A significant proportion of newly synthesized glycosaminoglycans in the medium was identified as hyaluronic acid. Its synthesis rate followed a time course similar to that of total glycosaminoglycans. There was a progressive decline of the fractional synthesis rate of hyaluronic acid from an initial value of 0.7 down to 0.3 on the 8 th day of culture. Complementary results were obtained by measuring the chemical amount of hyaluronic acid in the medium of fat-storing cells, using a radiometric assay procedure. It is shown in figure 6 that the amount of hyaluronic acid produced daily in fat-storing cell cultures increased almost 5 fold between the 2nd and 6th culture day. When related to the DNA content, fat-storing cells synthesized on the 4th day $4.2 \pm 0.8 \mu \mathrm{g}$ hyaluronate per $\mathrm{mg}$ DNA per hour $(n=4)$. More than 0.8 of the total hyaluronate was found in the medium. The hyaluronic acid concentration in the medium of Kupffer cell cultures was much lower; the synthesis rate of hyaluronate on the 3 rd day of culture was calculated to be 1.3 $\pm 0.4 \mu \mathrm{g} / \mathrm{mg}$ DNA per hour $(\mathrm{n}=4)$. In hepatocyte cultures hyaluronate was not detectable with the radiometric assay or by radioisotopic labeling.

Fig. 5. Culture time-dependent changes of the incorporation of $\left[{ }^{3} \mathrm{H}\right]$ glucosamine into total glycosaminoglycans (a) and hyaluronic acid (c) in the medium of fat-storing cells. The synthesis of labeled hyaluronate is expressed as a fraction of total labeled glycosaminoglycans (b). The inset in figure $5 \mathrm{~b}$ demonstrates the changes of DNA per culture plate. Cells were seeded at a density of 0.25 $\cdot 10^{6}$ cells $/ 2 \mathrm{~cm}^{2}$. Mean values $\pm S$. D. of 4 wells are given.
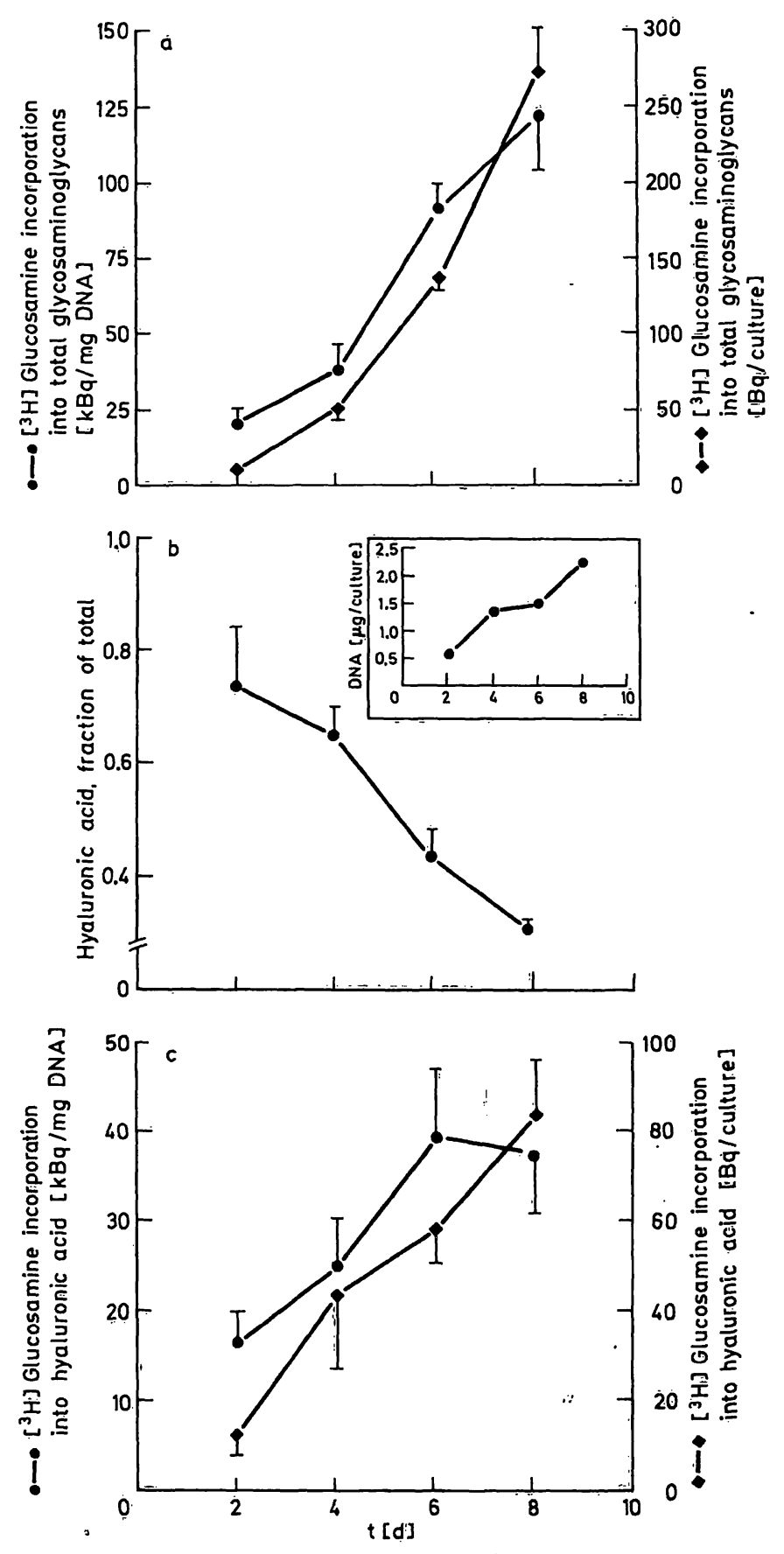

is

J. Clin. Chem. Clin. Biochem. / Vol. 27, 1989 / No. 3 


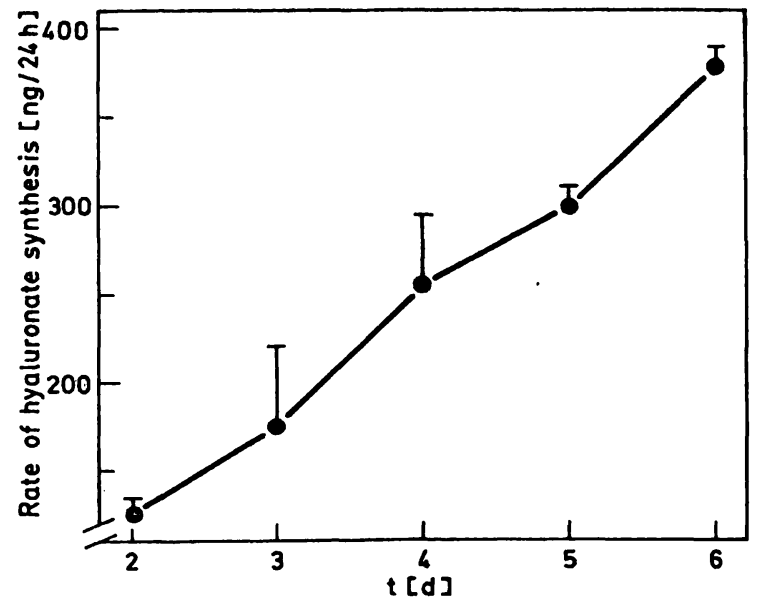

Fig. 6. Synthesis rate of hyaluronate in the medium of fatstoring cells at various times of culture. Cells were seeded at a density of $0.25 \cdot 10^{6}$ cells $/ 2 \mathrm{~cm}^{2}$ well. The medium was changed daily and used for determination of the hyaluronate concentration. Mean values $\pm S$. $D$. of 5 wells are given.

\section{Discussion}

Of the 4 types of glycosaminoglycans, identified in the extracellular matrix of the liver $(25-27), 3$ species (heparan sulphate, chondroitin sulphate, dermatan sulphate) are supposed to exist as proteoglycans, whose functions are only incompletely understood $(44,45)$. These macromolecules consist of a core protein to which a number of unbranched, sulphated (polyanionic) carbohydrate side chains (glycosaminoglycans) are covalently attached (46). The proteoglycans can interact non-covalently with hyaluronic acid, a large molecular weight, non-sulphated carbohydrate chain devoid of a core protein $(46,47)$. Heparan sulphate is the predominant type in liver (2527,29 ). Its location is not restricted to the extracellular matrix, and it is also found in high concentrations in the pericellular coat (glycocalyx) of hepatocytes (48, 49) and in intracellular compartments including the nucleus $(50,51)$. The structure (52) and cellular origin of heparan sulphate have been studied extensively. Hepatocytes were identified as the main cellular source of heparan sulphate $(34,53-55)$. In fact, in early cultures of these cells heparan sulphate was almost the only type of glycosaminoglycan produced (55). In long-term cultures ( $>4$ th/5th day) hepatocytes were shown to produce increasing amounts of other sulphated glycosaminoglycans, as well as hyaluronic acid (56). The conclusions drawn from in vitro studies on type-specific synthesis of connective tissue molecules are critically dependent on the purity of the cell culture. The problem of the contamination of hepatocyte cultures by fat-storing cells has been stressed in a recent study on collagen synthesis of hepatocytes (57). Although, in the present study, we also cannot definitely exclude the presence of a fraction of contaminating fat-storing cells in the hepatocyte cultures, it is unlikely that the degree of contamination is significant, because

(i) under the light microscope we did not observe vitamin A-autofluorescence, or immunofluorescence staining of desmin in fat-storing cells,

(ii) in the medium of hepatocyte cultures only trace amounts of dermatan sulphate, the predominant type in the medium of fat-storing cells, were found, and

(iii) hyaluronate, the major glycosaminoglycan in the medium of fat-storing cells, was not detectable in hepatocyte cultures.

We therefore consider that the fraction of condroitin sulphate in the medium of hepatocytes is a true synthesis product of liver parenchymal cells. This result confirms previous findings in short-term liver cell suspension cultures, in which a quantitatively similar fraction of nitrous acid resistant glycosaminoglycans was identified (58). The composition of proteoglycans in the medium and cell fraction of fat-storing cells resembled that described previously (23). Kupffer cells contained almost equal amounts of all sulphated glycosaminoglycan types in the cell and medium fraction, respectively. Only fat-storing cells secrete most of their newly synthesized proteoglycans into the extracellular space.

For several reasons, the data on the incorporation rates of radiolabeled isotopic precursors are difficult to interpret in terms of the synthesis rates of total and specific types of sulphated proteoglycans:

(i) The rates of cellular uptake of $\left[{ }^{35} \mathrm{~S}\right]$ sulphate and $\left[{ }^{3} \mathrm{H}\right]$ glucosamine and the respective precursor pool sizes might be different between the three cell types. The determination of the specific radioactivity of the immediate precursors, i. e. UDP-N-acetyl glucosamine/-galactosamine (40) and 3'phosphoadenosine5'-phosphosulfate (PAPS) (59) was found to be difficult in the cell cultures and, hence, our data are not corrected for this potential source of error.

(ii) The incorporation of $\left[{ }^{35} \mathrm{~S}\right]$ sulphate measures primarily the sulphation, a final step in the synthesis of the carbohydrate chain, which implies that variations in the degree of sulphation (over- and undersulphation) might result in over- or underestimation of the respective synthesis rates. Oversulphated isomers of dermatan sulphate containing disulphated disaccharides are present in normal liver $(26,27)$. Therefore, labeled glucosamine was used as an alternative precursor for glycosaminoglycan synthesis. 
(iii) The proportion of the synthesis rates between the cell types is dependent on the reference parameter (cell number, DNA, protein).

(iv) As exemplified by hyaluronate in the medium of fat-storing cell cultures, the culture time is an important determinant of the synthesis rate and even of the composition of glycosaminoglycans.

As in other cell cultures, connective tissue synthesis is turned on and qualitatively changed with advancing culture time $(8,9,12,21,56)$, due to phenotypic adaptation of cells in culture. The loss of extracellular matrix during cell isolation is important in gene expression, as it may introduce different alterations in gene regulation and abnormal gene expression in the various cell types. We tried to standardize our determination on the 3rd day of culture. The limitations, which are inherent in most cell culture studies, do not allow an extrapolation from the in vitro incorporation rates to in situ synthesis rates. Presently, there are no techniques available allowing in situ identification of the cellular sources and quantification of the production rates of individual proteoglycans. According to our results, fat-storing cells are a major source of connective tissue proteoglycans in liver. These cells synthesize and secrete significant amounts of a broad spectrum of those proteoglycans (23) and hyaluronate (24) which are found in the matrix of normal liver. The proteoglycans are bound at least partially to hepatocellular surfaces (60) and, thus, will influence the microenvironment, intercellular communication and other cell surface functions of the parenchymal cell. Since liver endothelial cells take up and degrade hyaluronic acid $(61,62)$, a fraction of that glycosaminoglycan secreted by fat-storing cells might follow this pathway. Presently, the functional significance of sulphated proteoglycans and of hyaluronic acid produced by fat-storing cells is unknown. In liver injury, proliferation and transformation of fat-storing cells (63) might be the main mechanism of local amplification of proteoglycan and hyaluronate synthesis. Interestingly, mitotic activity $(39,64)$ and the production rates of total glycosaminoglycans (65) and of hyaluronate (66) in fat-storing cells in vitro are significantly stimulated by secretions of activated Kupffer cells. This observation indicates metabolic cooperativity between the various cell types in the formation of the hepatic extracellular matrix. Neither Kupffer cells nor hepatocytes have been shown so far to contribute directly to proteoglycan accumulation during fibrogenesis. The results of this comparative study stress the potential importance of fat-storing cells in the metabolism of glycosaminoglycans in the extracellular matrix under normal and pathological conditions.

\section{Acknowledgement}

The study was financially supported through grant Gr 463/8-1 from the Deutsche Forschungsgemeinschaft.

\section{References}

1. Rauterberg, J., Voss, B., Pott, G. \& Gerlach, U. (1981) Klin. Wochenschr. 59, 767-779.

2. Gressner, A. M. (1987) Med. Klin. 82, 700-710.

3. Rojkind, M. (1988) In: The Liver: Biology and Pathobiology (Arias, I. M., Jakoby, W. B., Popper, H., Schachter, D. \& Shafritz, D. A., eds.) Raven Press Ltd. (New York) pp. $707-716$

4. Rojkind, M. \& Kershenobich, D. (1986) In: The Liver Annual 5 (Arias, I. M., Frenkel, M. \& Wilson, J. H. P., eds.) Elsevier Science Publishers B. V. pp. 210-224.

5. Saber, M. A., Zern, M. A. \& Shafritz, D. A. (1983) Proc. Natl. Acad. Sci. USA 80, 4017-4020.

6. Hatahara, T. \& Seyer, J. M. (1982) Biochim. Biophys. Acta $716,431-438$.

7. Konomi, H., Hata, R.-I., Sano, J., Sunada, H. \& Nagai, Y. (1982) Biomed. Res. 3, $341-344$.

8. Hata, R.-I., Ninomiya, Y., Sano, J., Konomi, H., Hori, H., Sunada, H., Tanaka, S., Kabuki, K., Nagai, Y. \& Tsukada, Y. J. (1985) Cell Physiol. 122, 333-342.

9. Guzelian, P. S., Qureshi, G. D. \& Diegelmann, R. F. (1981) Collagen Res. 1, 83-93.

10. Diegelmann, R. F., Guzelian, P. S., Gay, R. \& Gay, S. (1983) Science 219, 1343-1345.

11. Diegelmann, R. F. \& Lindblad, W. J. (1985) Fundamental Appl. Toxicol. 5, 219-227.

12. Diegelmann, R. F. (1986) In: Isolated and cultured hepatocytes (Guillouzo, A. \& Guguen-Guillouzo, C. eds.) John Libbey Eurotext Ltd., pp. 209-224.

13. Chojkier, M. (1986) J. Clin. Invest. 78, 333-339.

14. Malizia, G., Giannuoli, G., Caltagirone, M., Pisa, R. \& Pagliaro, L. (1987) Lancet $I, 1055-1057$.

15. De Leeuw, M. A., McCarthy, S. P., Geerts, A. \& Knook, D. L. (1984) Hepatology 4, 392-403.

16. Enzan, H. (1984) Recent Advances in RES Research 24, $48-56$.

17. Davis, B. H., Pratt, B. M. \& Madri, J. A. (1987) J. Biol. Chem. 261, 10280-10286.

18. Friedman, S. L., Roll, F. J., Boyles, J. \& Bissell, D. M. (1985) Proc. Natl. Acad. Sci. USA 82, 8681-8685.

19. Clement, B., Grimaud, J.-A., Campion, J.-P., Deugnier, Y. \& Guillouzo, A. (1986) Hepatology 6, 225-234.

20. Clement, B., Emonard, H., Rissel, M., Druguet, M., Grimaud, J.-A., Herbage, D., Bourel, M. \& Guillouzo, A. (1984) Cell. Molec. Biol. 30, 489-496.

21. Ramadori, G., Rieder, H., Knittel, Th., Dienes, H. P. \& Meyer zum Büschenfelde, K.-H. (1987) J. Hepatol. 4, 190197.

22. Maher, J. J., Friedman, S. L., Roll, F. J. \& Bissell, D. M. (1988) Gastroenterology 94, 1053 =1062. 
23. Schäfer, S., Zerbe, O. \& Gressner, A. M. (1987) Hepatology 7, 680-687.

24. Gressncr, A. M. \& Haarmann, R. (1988) Biochem. Biophys. Res. Commun. 151, 222-229.

25. Stuhlsatz, H. W., Vierhaus, S., Gressner, A. M. \& Greiling, H. (1983) In: Structural carbohydrates in the liver (Popper, H., Reutter, W., Gudat, F. \& Köttgen, E., eds.) MTP Press Ltd. (Lancaster) 650-651.

26. Murata, K., Akashio, K. \& Ochiai, Y. (1984) HepatoGastroenterol. 31, $261-265$.

27. Murata, K., Ochiai, Y. \& Akashio, K. (1985) Gastroenterology 89, $1248-1257$.

28. Olds, G. R., Finegan, C. \& Kresina, T. F. (1986) Gastroentcrology 9l, 1335-1342.

29. Kojima, J., Nakamura, N., Kanatani, M. \& Ohmori, K. (1975) Cancer Res. 35, 542-547.

30. Kojima, J., Nakamura, N., Kanatani, M. \& Akiyama, M. (1982) Cancer Res. 42, 2857-2860.

31. Wakc, K. (1980) Intern. Rev. Cytol. 66, 303-353.

32. Alerman, K. (1986) Histochem. J. 18, 279-305.

33. Seglen, P. O. (1976) In: Methods in cell biology (Prescotl, D. M., ed.) Academic Press (New York) Vol. XIII, pp. 29-83.

34. Gressner, A. M. \& Pfeiffer, T. J. (1986) J. Clin. Chem. Clin. Biochem. 24, 821-829.

35. De Leeuw, A. M., McCarthy, S. P., Geerts, A. \& Knook, D. L. (1984) Hepatology 4, 392-403.

36. Yokoi, Y., Namihisa, T., Kuroda, H., Komatsu, I., Miyazaki, A., Watanabe, S. \& Usui, K. (1984) Hepatology 4, $709-714$

37. Gressner, A. M. \& Zerbe, O. (1987) J. Hepatol. 5, 299310.

38. Knook, D. L., Blansjaar, N. \& Secyster, E. C. H. (1977) Exp. Cell. Res. 109, 317-329.

39. Zcrbe, O. \& Gressner, A. M. (1988) Exp. Mol. Pathol. 49, $87-101$.

40. Gressner, A. M., Pazen, H. \& Greiling, H. (1977) Hoppe Seyler's Z. Physiol. Chem. 358, 825-833.

41. Laurent, U. B. G. \& Tengblad, A. (1980) Anal. Biochem. $109,386-394$

42. Labarca, C. \& Paigen, K. (1980) Anal. Biochem. 102, $344-$ 352.

43. Lowry, O. H., Roscbrough, N. J., Farr, A. L. \& Randall, R. J. (1951) J. Biol. Chem. 193, 265-275.
44. Gressner, A. M. (1983) Hepato-Gastrocnterol. 30, $225-$ 229.

45. Arenson, D. M. \& Bissell, D. M. (1987) Gastroenterology 92, 536-540.

46. Poole, A. R. (1986) Biochem. J. 236, 1-14.

47. Iozzo, R. V. (1985) Lab. Invest. 53, 373-396.

48. Kjellen, L., Pettersson, I. \& Höök, M. (1981) Proc. Natl. Acad. Sci. USA 78, $5371-5375$.

49. Bertrand, F., Veissiére, D. \& Picard, J. (1983) Int. J. Biochem. 15, 17-26.

50. Ishihara, M., Fedarko, N. S. \& Conrad, H. E. (1986) J. Biol. Chem. 261, 13575-135080.

51. Fedarko, N. S. \& Conrad, H. E. (1986), J. Cell. Biol. 102, 587-599.

52. Oldberg, A., Kjellén, L. \& Höök, M. (1979) J. Biol. Chem. $254,8505-8510$.

53. Oldberg, A., Höök, M., Öbrink, B., Pertoft, H. \& Rubin, K. (1977) Biochem. J. 164, 75-81.

54. Sudhakaran, P. R., Sinn, W. \& von Figura, K. (1980) Biochem. J. 192, 395-402.

55. Prinz, R., Klein, U., Sudhakaran, P. R., Sinn, W., Ullrich, K. \& von Figura, K. (1980) Biochim. Biophys. Acta 630 , $402-413$.

56. Ninomiya, Y., Hata, R.-I. \& Nagai, Y. (1981) Biochim. Biophys. Acta 675, 248-255.

57. Maher, J. J., Bissell, D. M., Friedman, S. L. \& Roll, F. J. (1988) J. Clin. Invest. 82, 450-459.

58. Gressner, A. M. \& Grouls, P. (1982) Digestion 23, 259264.

59. Gressncr, A. M., Heinrigs, S. \& Grouls, P. J. (1982) J. Clin. Chem. Clin. Biochom. 20, 15-24.

60. Kirch, H. C., Lammers, M. \& Gressner, A. M: (1987) Int. J. Biochem. 19, 1119-1126.

61. Smedsrod, B., Pertoft, H., Eriksson, S., Fraser, J. R. E. \& Laurent, T. C. (1984) Biochem. J. 223, 617-626.

62. Fraser, J. R. E., Alcorn, D., Laurent, T. C., Robinson, A. D. \& Ryan, G. B. (1985) Cell. Tissue Res. 242, 505-510.

63. Mak, K., Leo, M. A. \& Lieber, C. S. (1984) Gastroenterology 87, 188-200.

64. Shiratori, Y., Geert, A., Ichida, T., Kawase, T. \& Wissc, E. (1986) J. Hepatol. 3, 294-303.

65. Gressner, A. M. \& Zerbe, O. (1987) J. Hepatol. 5, 299310.

66. Gressner, A. M. \& Haarmann, R. (1988) J. Hepatol. 7, $310-318$

Pror. Dr. A. M. Gressner

Leiter der Abteilung für

Klinische Chemie

und Zentrallaboratorium

Klinikum der Philipps-Universität

Baldingerstraße

D-3550 Marburg 


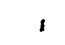

